\title{
EDITORIAL
}

\section{PARASITOLOGIA LATINOAMERICANA: A NEW STAGE FOR TWO PARASITOLOGY JOURNALS EDITED IN CHILE}

With the current issue, we begin the publication of Parasitología Latinoamericana, a new journal that will be the continuation of two prestigious journals in the field of Parasitology edited in Chile: Boletín Chileno de Parasitología and Parasitología al Día.

Different circumstances of diverse origin have made it necessary to merge these two journals with the hope that the emerging one will represent the addition and the strength that each one had in its separate form.

Both journals have published hundreds of valuable contributions from Chilean, Latinamerican and foreigns authors from many countries in various subjects dealing with taxonomy, biology and biochemistry of parasites, clinical, immunological and epidemiological aspects as well as control measures for different parasitic diseases from man and animals. The same content will be maintained in Parasitología Latinoamericana.

In 1991, the Boletín Chileno de Parasitología and Parasitología al Día published volumes number 56 and 25, respectively. As Boletín Chileno de Parasitología appeared earlier (in 1946) its numeration will be kept, therefore the new journal Parasitología Latinoamericana will start with volume number 57.

The Federación Latinoamericana de Parasitología (FLAP) was informed about this merger during the XV Latinamerican Congress of Parasitology held in October, 2001, in Sao Paulo, Brasil. On that occasion, it was agreed that Parasitología Latinoamericana will be its official instrument, offering parasitologists of the region the opportunity to publish and promote the progress of this scientific field as it had previously been done by Parasitología al Día.

Contributions, readers and those interested, should address their correspondence to Parasitología Latinoamericana, Casilla 9183, Santiago, 1, Chile or Fax (56-2) 5416840.

Authors should send their papers in $31 / 2$ diskettes saved in Word 6.0 or higher with a manuscript of the article as well. All instructions are indicated in the Journal itself or in its electronic version: www.scielo.cl

Our team is highly motivated with the new journal as it stimulates us to keep going with more energy and responsibility in its editorial work. Nonetheless, this challenge requires continuity and development, demanding the effort not only of a few, but the generous collaboration of Latinamerican parasitologists who will collaborate in this important commitment that we are now initiating.

Héctor Alcaíno Editor 